\title{
THE MEASURMENT OF THE PERCEPTION OF CUSTOMERS TOWARDS INTERNET BANKING SERVICES IN RAMANATHAPURAM DISTRICT
}

\section{Mrs. P. Sountharya}

Dr. G. Karunanithi*

Ph.D., Research Scholar (Full Time), PG and Research Department of Commerce, Government Arts College, Paramakudi, Ramanathapuram Dist.

Assistant Professor and Research Supervisor, PG and Research Department of Commerce, Government Arts College, Paramakudi, Ramanathapuram Dist. *Corresponding Author

ABSTRACT Customers are the most important assets of any business. The success and failure of any business depends upon how far they satisfy the expectation of their customers. The increase in volume of customers automatically lead to deterioration in quality of customer services. Banks are an important social organization rendering valuable financial services to its customers. Realizing the importance of customer service in banks, recommendations are made by various committees to improve the services quality of banks. The nationalization of major commercial banks led to 'Mass banking' which in turn increased the volume of customers. In the present study primary and secondary data have been used. In the study convenient random sampling technique has been adopted for selecting a sample of 225 respondents who have used internet banking in Ramanathapuram district in selected banks through questionnaire. The present study focuses on components used for measuring the satisfaction of the respondents towards internet banking, level of satisfaction towards banking products and services and problems faced by the respondents in internet banking It is clear from that responsiveness (Promptness with which employees willing to serve) is a factor which is considered for measuring the perception of the respondents towards internet banking followed by courteous service (Individual attention and make them feel as special).

\section{KEYWORDS :}

\section{INTRODUCTION}

Customer perception is an outcome of purchase and use resulting from the comparison of the rewards and costs vis-àvis customers' expectations and actual performance of the product purchased in relation to the expected results. Customer perception is a measure that fulfills the general expectations of a customer and how far and/or close does the existing bank come to the customer's ideal bank in his mind. Customers are the most important assets of any business. The success or failure of any business depends upon how far they satisfy the expectation of their customers. The increase in the volume of customers automatically leads to deterioration in quality of customer services. Banks are an important social organization rendering valuable financial services to its customers. Realizing the importance of customer service in banks, recommendations are made by various committees to improve the services quality of banks. The nationalization of major commercial banks led to 'Mass banking' which in turn increased the volume of customers.

\section{Statement of the Problem}

The tremendous advances in technology and the aggressive infusion of information technology had brought in a paradigm shift in banking operations. For the banks, technology has emerged as a strategic resource for achieving higher efficiency, control of operations, productivity and profitability. For customers, it is the realization of their 'anywhere, anytime, anyway' banking dream. This has prompted the banks to embrace technology to meet the increasing customer expectation and face the tough competition.

The recent trends show that most 'brick and mortar' banks are shifting from a 'product-centric' model to a 'customer-centric' model as they develop their new e-banking capabilities. They have, over a long time, been using electronic and telecommunication networks for delivering a wide range of value added products and services. The delivery channels include direct dial-up connections, private networks, public networks etc and the devices include telephone, Personal Computers including the Automated Teller Machines, etc.
With the popularity of PCs, easy access to Internet and World Wide Web (WWW), banks increasingly use Internet as a channel for receiving instructions and delivering their products and services to their customers. This form of banking is generally referred to as Internet Banking, although the range of products and services offered by different banks vary widely both in their content and sophistication. Hence, it is essential to study the measurement of the perception of customers towards internet banking services in Ramanath apuram district.

\section{OBJECTIVES OF THE STUDY}

By means of the present study, the researcher endeavors to undertake a comprehensive enquiry to fulfill the objectives set out below:

- To examine the components used to measure the satisfaction of the respondents towards internet banking.

- To measure the level of satisfaction of the respondents towards banking products/services.

- To investigate the problems faced by the respondents regarding internet banking.

- To offer suitable suggestions for improving the services of internet banking based on the finding of the study.

\section{Scope of the Study}

The present study focuses on components used for measuring the satisfaction of the respondents towards internet banking, level of satisfaction towards banking products and services and problems faced by the respondents in internet banking.

\section{Methodology}

In the present study primary and secondary data have been used. Convenient random sampling technique has been adopted for selecting a sample of 225 respondents who have used internet banking in Ramanathapuram district in selected banks through questionnaire. The collected data are analyzed by classifying and tabulating. The secondary data have been collected from books, journals, magazines, report \& websites. The primary data have been analysed by using the following statistical tools such as ; Percentage analysis, Likert's five point scaling technique, Pearson Correlation Co- 
efficient, Ranking, Mean and Standard deviation.

\section{Analytical Framework}

Simple ranking technique has been used to analyse the factors considered while selecting a particular bank. The level of the perception of the respondents towards products and services has been measured with the help of mean and standard deviation. In case of products, the total perception score of a respondent is obtained by adding up scores of all the 16 statements. In case of services, the total perception score of a respondent is obtained by adding up scores of all the 22 statements. The level of perception has been classified into three categories namely low level, medium level and high level perception for analytical purposes.

The score values greater thanX + S.D. and the score values less than X - S.D. have been classified as high level of perception and low level of perception, respectively. The score values between (X+ S.D.) and (X-S.D.) have been classified as medium level of perception. $\mathrm{X}$ and S.D. are the arithmetic mean and standard deviation calculated from the score value of 225 respondents.

Level of Perception for products

The calculated values of X and S.D. are 44.61 and 2.34 respectively.

Therefore

$\mathrm{X}+$ S.D. $(44.61+2.34)=47.26=47$ and above - High level perception

$X-$ S.D. $(44.61-2.34)=42.27=42$ and below - Low Level perception

(X - S.D) and (X + S.D.) between 42 to 47) - Medium Level perception

Level of Perception for services

The calculated values of $\mathrm{X}$ and S.D. are 73.21 and 5.48 respectively.

Therefore

$X+$ S.D. $(73.21+5.48)=78.69=79$ and above - High level perception

Table 2 Components Used for Measuring the Perception of the Respondents towards Internet Banking

\begin{tabular}{|c|c|c|c|c|c|}
\hline CONVEIENCE & S.A & $\bar{A}$ & $\mathbf{N}$ & D.A & S.D.A \\
\hline Convenient location and Timings & 37 & 46 & 41 & 69 & 32 \\
\hline Reduced processing time & 59 & 58 & 33 & 36 & 39 \\
\hline Low service charges & 76 & 63 & 47 & 11 & 28 \\
\hline Easy to maintain banking transaction activity & 78 & 66 & 15 & 29 & 37 \\
\hline Provide a wide range of products and services & 60 & 11 & 28 & 81 & 45 \\
\hline $\begin{array}{l}\text { COURTEOUS SERVICE } \\
\end{array}$ & S.A & $\bar{A}$ & $\mathbf{N}$ & D.A & S.D.A \\
\hline Welcome the customers with smile & 58 & 16 & 38 & 72 & 41 \\
\hline A positive perception and willingness to serve the customers & 82 & 54 & 16 & 28 & 45 \\
\hline Individual attention and make them feel special & 99 & 16 & 75 & 17 & 18 \\
\hline Employees are courteous & 43 & 42 & 30 & 83 & 27 \\
\hline Easy to approach and contact & 37 & 30 & 68 & 45 & 45 \\
\hline EMPLOYEE COMPETENCE & S.A & $\bar{A}$ & $\mathbf{N}$ & D.A & S.D.A \\
\hline Knowledge of the internet banking and their products and services & 85 & 62 & 29 & 14 & 35 \\
\hline Employees are more skilled and capable of using Internet Banking & 67 & 32 & 41 & 21 & 64 \\
\hline The banks staffs are able to provide professional advice to its customers & 65 & 54 & 44 & 53 & 9 \\
\hline Bank employees know what your needs are and how the banks product can satisfy you & 17 & 68 & 19 & 55 & 66 \\
\hline Having patience and proper guidance to all services & 85 & 17 & 42 & 17 & 64 \\
\hline $\begin{array}{l}\text { RESPONSIVENESS } \\
\end{array}$ & S.A & $\bar{A}$ & $\mathbf{N}$ & D.A & S.D.A \\
\hline Responding to customer enquires immediately & 68 & 56 & 42 & 25 & 34 \\
\hline To help customers and provide prompt service & 65 & 76 & 63 & 18 & 3 \\
\hline The bank staffs adequately communicate information to their customers & 95 & 22 & 61 & 32 & 15 \\
\hline Promptness with which employees willing to serve & 89 & 78 & 35 & 18 & 5 \\
\hline Resolving problems quickly & 107 & 25 & 71 & 16 & 6 \\
\hline ASSURANCE & S.A & $\bar{A}$ & $\mathbf{N}$ & D.A & S.D.A \\
\hline Maintaining the customer secrecy & 86 & 22 & 41 & 26 & 50 \\
\hline
\end{tabular}

22 GJRA - GLOBAL JOURNAL FOR RESEARCH ANALYSIS
$X-$ S.D. $(73.21-5.48)=67.73=68$ and below - Low Level perception

(X - S.D) and (X + S.D.) between 68 to 79) - Medium Level perception

Karl Pearson's Co-efficient of Correlation has been used to examine the relationship between the level of perception of the respondents towards products and services. Chi square test respondents and their level of perception towards products/services.

Table 1

Level of perception of the respondents towards products

\begin{tabular}{|c|c|c|c|c|}
\hline \multirow{2}{*}{ Level } & \multicolumn{2}{|c|}{ Products } & \multicolumn{2}{c|}{ Services } \\
\cline { 2 - 5 } & $\begin{array}{c}\text { No. of } \\
\text { Respondents }\end{array}$ & Percentage & $\begin{array}{c}\text { No. of } \\
\text { Respondents }\end{array}$ & Percentage \\
\hline High & 82 & 36.44 & 69 & 30.67 \\
\hline Medium & 104 & 46.22 & 134 & 59.56 \\
\hline Low & 39 & 17.33 & 22 & 9.78 \\
\hline Total & 225 & 100 & 225 & 100 \\
\hline
\end{tabular}

Source: Primary data

Regarding products, 104 (46.22 per cent) have medium level perception, 82 (36.44 per cent) have high level perception and 39 (17.33 per cent) have low level perception towards products. Regarding services, 134 (59.56 per cent) have medium level perception, 69 (30.67 per cent) have high level perception and 22 (9.78 per cent) have low level perception towards services.

Pearson correlation co-efficient has been used to analyse the level of perception towards products and services. Correlation value $(r)=0.962$ which indicates that there is a high degree of positive correlation between the level of perception of the respondents towards products and services. The Components Used for Measuring the Perception of the Respondents towards Internet Banking. has been used to analyse the socio-economic profile of the and services 


\begin{tabular}{|c|c|c|c|c|c|}
\hline Providing services at right time & 43 & 63 & 43 & 44 & 32 \\
\hline Providing accurate service & 65 & 40 & 18 & 93 & 9 \\
\hline Providing transparent service & 69 & 38 & 14 & 75 & 29 \\
\hline Solving the problems of customers & 54 & 64 & 15 & 82 & 10 \\
\hline $\begin{array}{ll}\text { SECURITY/PRIVACY } \\
\end{array}$ & S.A & $\bar{A}$ & $\mathbf{N}$ & D.A & S.D.A \\
\hline Minimise the risk & 44 & 53 & 12 & 10 & 35 \\
\hline Safe for the customers to use the internet banking & 59 & 30 & 41 & 53 & 10 \\
\hline There are guarantees in internet banking & 21 & 23 & 32 & 68 & 86 \\
\hline Protecting the data and the information & 68 & 19 & 66 & 27 & 65 \\
\hline Customers feel safe in their transactions with the bank & 85 & 12 & 20 & 71 & 64 \\
\hline \begin{tabular}{|c|} 
BANK PREMISES \\
\end{tabular} & S.A & $\bar{A}$ & $\mathbf{N}$ & D.A & S.D.A \\
\hline The inside ambience and the layout of the bank is eye catching with adequate sitting facility & 40 & 67 & 23 & 52 & 225 \\
\hline The interior design of the premises facilitates the transactions & 73 & 33 & 30 & 29 & 225 \\
\hline Easy accessibility of broachers and pamphlets & 40 & 12 & 31 & 61 & 225 \\
\hline Parking facilities & 42 & 91 & 10 & 5 & 225 \\
\hline Drinking water and other facilities & 41 & 13 & 68 & 15 & 225 \\
\hline $\begin{array}{l}\text { HANDLING COMPLAINTS } \\
\end{array}$ & S.A & $\bar{A}$ & $\mathbf{N}$ & D.A & S.D.A \\
\hline The bank staff listens to the complaints very patiently & 68 & 40 & 76 & 19 & 225 \\
\hline The bank staff apologise if they have committed any mistake & 54 & 35 & 19 & 32 & 225 \\
\hline The bank staff are ready to correct mistakes & 42 & 54 & 60 & 14 & 225 \\
\hline Solving verbal complaints immediately by the managers & 39 & 39 & 33 & 28 & 225 \\
\hline $\begin{array}{l}\text { The bank send acknowledgements within } 24 \text { hours the receipt of written complaints from the } \\
\text { customers }\end{array}$ & 56 & 64 & 17 & 26 & 225 \\
\hline RETAIL BANKING & S.A & $\bar{A}$ & $\mathbf{N}$ & D.A & S.D.A \\
\hline \multicolumn{6}{|l|}{ Lesser time taken to the following activities: } \\
\hline Open an account & 67 & 27 & 12 & 52 & 67 \\
\hline Issue a draft, cheque book, passbook and ATM card & 52 & 42 & 61 & 38 & 32 \\
\hline Answer routine customer queries account balance, cheque clearing status, interest rates etc & 81 & 33 & 22 & 51 & 38 \\
\hline Give a locker and transact the locker facility & 63 & 71 & 46 & 28 & 17 \\
\hline Issue an account statement & 47 & 56 & 41 & 62 & 19 \\
\hline
\end{tabular}

Source: Primary data

Weighted Mean score analysis has been used to analyse the components used for measuring the perception of the respondents towards internet banking. The responses given by the respondents as Strongly Agree, Agree, no opinion, disagree and strongly disagree are multiplied by 5,4,3,2, and 1 . Total score has been found out and mean score is obtained by dividing the total score by number of respondents The mean score results are given in Table 3.

Table 3 Components Used for Measuring the Perception of the Respondents towards Internet Banking - Weighted Mean Score Analysis

\begin{tabular}{|l|c|c|c|c|c|c|c|}
\hline \multicolumn{1}{|c|}{ CONVEIENCE } & S.A & A & N & D.A & S.D.A & Total score & Mean score \\
\hline Convenient location and Timings & 185 & 184 & 123 & 138 & 32 & 662 & 2.94 \\
\hline Reduced processing time & 295 & 232 & 99 & 72 & 39 & 737 & 3.28 \\
\hline Low service charges & 380 & 252 & 141 & 22 & 28 & 823 & 3.66 \\
\hline Easy to maintain banking transaction activity & 390 & 264 & 45 & 58 & 37 & 794 & 3.53 \\
\hline Provide a wide range of products and services & 300 & 44 & 84 & 162 & 45 & 635 & 2.82 \\
\hline \multicolumn{1}{|c|}{ COURTEOUS SERVICE } & & & & & & \\
\hline Welcome the customers with smile & 290 & 64 & 114 & 144 & 41 & 653 & 2.90 \\
\hline Apositive perception and willingness to serve the customers & 410 & 216 & 48 & 56 & 45 & 775 & 3.44 \\
\hline Individual attention and make them feel special & 495 & 64 & 225 & 34 & 18 & 836 & 3.72 \\
\hline Employees are courteous & 215 & 168 & 90 & 166 & 27 & 666 & 2.96 \\
\hline Easy to approach and contact & 185 & 120 & 204 & 90 & 45 & 644 & 2.86 \\
\hline \multicolumn{1}{|c|}{ EMPLOYEE COMPETENCE } & & & & & & \\
\hline Knowledge of the internet banking and their products and services & 425 & 248 & 87 & 28 & 35 & 823 & 3.66 \\
\hline Employees are more skilled and capable of using Internet Banking & 335 & 128 & 123 & 42 & 64 & 692 & 3.08 \\
\hline $\begin{array}{l}\text { The banks staff are able to provide professional advice to its } \\
\text { customers }\end{array}$ & 325 & 216 & 132 & 106 & 9 & 788 & 3.50 \\
\hline $\begin{array}{l}\text { Bank employees know what your needs are and how the banks } \\
\text { product can satisfy you }\end{array}$ & 85 & 272 & 57 & 110 & 66 & 590 & 2.62 \\
\hline Having patience and proper guidance to all services & 425 & 68 & 126 & 34 & 64 & 717 & 3.19 \\
\hline \multicolumn{1}{|c|}{ RESPONSIVENESS } & & & & & & 340 \\
\hline Responding to customer enquires immediately & 224 & 126 & 50 & 34 & 774 & 3.44 \\
\hline To help customers and provide prompt service & 304 & 189 & 36 & 3 & 857 & 3.81 \\
\hline
\end{tabular}




\begin{tabular}{|c|c|c|c|c|c|c|c|}
\hline $\begin{array}{l}\text { The bank staff adequately communicate information to their } \\
\text { customers }\end{array}$ & 475 & 88 & 183 & 64 & 15 & 825 & 3.67 \\
\hline \begin{tabular}{|l|l} 
Promptness with which employees willing to serve &
\end{tabular} & 445 & 312 & 105 & 36 & 5 & 903 & 4.01 \\
\hline Resolving problems quickly & 535 & 100 & 213 & 32 & 6 & 886 & 3.94 \\
\hline \multicolumn{8}{|l|}{ ASSURANCE } \\
\hline Maintaining the customer secrecy & 430 & 88 & 123 & 52 & 50 & 743 & 3.30 \\
\hline Providing services at right time & 215 & 252 & 129 & 88 & 32 & 716 & 3.18 \\
\hline Providing accurate service & 325 & 160 & 54 & 186 & 9 & 734 & 3.26 \\
\hline Providing transparent service & 345 & 152 & 42 & 150 & 29 & 718 & 3.19 \\
\hline Solving the problems of customers & 270 & 256 & 45 & 164 & 10 & 745 & 3.31 \\
\hline \multicolumn{8}{|l|}{$\begin{array}{l}\text { SECURITY/PRIVACY } \\
\end{array}$} \\
\hline Minimize the risk & 220 & 212 & 36 & 20 & 35 & 523 & 2.32 \\
\hline Safe for the customers to use the internet banking & 295 & 120 & 123 & 106 & 10 & 654 & 2.91 \\
\hline There are guarantees in internet banking & 105 & 92 & 96 & 136 & 86 & 515 & 2.29 \\
\hline Protecting the data and the information & 340 & 76 & 198 & 54 & 65 & 733 & 3.26 \\
\hline Customers feel safe in their transactions with the bank & 425 & 48 & 60 & 142 & 64 & 739 & 3.28 \\
\hline \multicolumn{8}{|l|}{$\begin{array}{l}\text { BANK PREMISES } \\
\end{array}$} \\
\hline $\begin{array}{l}\text { The inside ambience and the layout of the bank is eye catching } \\
\text { with adequate sitting facility }\end{array}$ & 215 & 160 & 201 & 46 & 52 & 674 & 3.00 \\
\hline The interior design of the premises facilitates the transactions & 300 & 292 & 99 & 60 & 29 & 780 & 3.47 \\
\hline Easy accessibility of broachers and pamphlets & 405 & 160 & 36 & 62 & 61 & 724 & 3.22 \\
\hline Parking facilities & 385 & 168 & 273 & 20 & 5 & 851 & 3.78 \\
\hline Drinking water and other facilities & 440 & 164 & 39 & 136 & 15 & 794 & 3.53 \\
\hline \multicolumn{8}{|l|}{$\begin{array}{l}\text { HANDLING COMPLAINTS } \\
\end{array}$} \\
\hline The bank staff listens to the complaints very patiently & 110 & 272 & 120 & 152 & 19 & 673 & 2.99 \\
\hline The bank staff apologise if they have committed any mistake & 425 & 216 & 105 & 38 & 32 & 816 & 3.63 \\
\hline The bank staff are ready to correct mistakes & 275 & 168 & 162 & 120 & 14 & 739 & 3.28 \\
\hline Solving verbal complaints immediately by the managers & 430 & 156 & 117 & 66 & 28 & 797 & 3.54 \\
\hline $\begin{array}{l}\text { The bank send acknowledgements within } 24 \text { hours the receipt of } \\
\text { written complaints from the customers }\end{array}$ & 310 & 224 & 192 & 34 & 26 & 786 & 3.49 \\
\hline \multicolumn{8}{|l|}{\begin{tabular}{|l|l|} 
RETAIL BANKING \\
\end{tabular}} \\
\hline \multicolumn{8}{|l|}{ Lesser time taken to the following activities: } \\
\hline Open an account & 335 & 108 & 36 & 104 & 67 & 650 & 2.89 \\
\hline Issue a draft, cheque book, passbook and ATM card & 260 & 168 & 183 & 76 & 32 & 719 & 3.20 \\
\hline $\begin{array}{l}\text { Answer routine customer queries account balance, cheque } \\
\text { clearing status, interest rates etc }\end{array}$ & 405 & 132 & 66 & 102 & 38 & 743 & 3.30 \\
\hline \begin{tabular}{|l|} 
Give a locker and transact the locker facility \\
\end{tabular} & 315 & 284 & 138 & 56 & 17 & 810 & 3.60 \\
\hline Issue an account statement & 235 & 224 & 123 & 124 & 19 & 725 & 3.22 \\
\hline
\end{tabular}

Source: Primary data

Table 4 depicts the dominant factor loadings of mean score analysis.

Table 4 Dominant Factor Loadings

\begin{tabular}{|l|l|c|c|}
\hline \multicolumn{1}{|c|}{ Factors } & \multicolumn{1}{|c|}{ Statements } & Mean score & Rank \\
\hline Convenience & Low service charges & 3.66 & III \\
\hline Courteous service & Individual attention and make them feel special & 3.72 & II \\
\hline Employee competence & Knowledge of the internet banking and their products and services & 3.66 & III \\
\hline Responsiveness & Promptness with which employees willing to serve & 4.01 & I \\
\hline Assurance & Solving the problems of customers & 3.31 & VIII \\
\hline Security/privacy & Customers feel safe in their transactions with the bank & 3.28 & IX \\
\hline Bank premises & Drinking water and other facilities & 3.53 & VII \\
\hline Handling complaints & The bank staff apologise if they have committed any mistake & 3.63 & V \\
\hline Retail banking & Give a locker and transact the locker facility & 3.60 & VI \\
\hline
\end{tabular}

Source: Primary data

It is clear from Table 4 that responsiveness (Promptness with which employees willing to serve) is a factors which is considered for measuring the perception of the respondents towards internet banking followed by courteous service (Individual attention and make them feel special).

\section{PROBLEMS FACED BY RESPONDENTS IN INTERNET BANKING}

Table 5 pinpoints the problems faced by the respondents in internet banking.

\begin{tabular}{|c|c|c|c|c|c|c|c|c|c|c|c|c|c|}
\hline \multirow[t]{2}{*}{ Problems } & \multicolumn{12}{|c|}{ Ranks } & \multirow[t]{2}{*}{ Total } \\
\hline & I & II & III & IV & V & VI & VII & VIII & IX & $\mathrm{X}$ & $\mathrm{XI}$ & XII & \\
\hline Delay in correcting the mistake & 46 & 54 & 22 & 22 & 6 & 4 & 5 & 12 & 10 & 35 & 7 & 2 & 225 \\
\hline Refusal to grant loans to eligible borrowers & 11 & 16 & 14 & 4 & 13 & 15 & 3 & 44 & 41 & 10 & 52 & 2 & 225 \\
\hline
\end{tabular}




\begin{tabular}{|l|c|c|c|c|c|c|c|c|c|c|c|c|c|}
\hline Unhelpful attitude and discourteous behaviour of staff members & 19 & 15 & 18 & 19 & 9 & 21 & 23 & 32 & 16 & 8 & 12 & 33 & 225 \\
\hline Delay in giving quick response & 29 & 23 & 14 & 17 & 29 & 6 & 22 & 21 & 27 & 5 & 9 & 23 & 225 \\
\hline Displayed invalid while typing actual PIN number & 15 & 27 & 15 & 18 & 10 & 18 & 30 & 23 & 37 & 6 & 21 & 5 & 225 \\
\hline Complication for transaction of e-banking & 43 & 19 & 7 & 13 & 24 & 22 & 6 & 7 & 3 & 17 & 12 & 52 & 225 \\
\hline Shortage of amount in ATM & 5 & 8 & 33 & 15 & 29 & 8 & 4 & 13 & 19 & 32 & 51 & 8 & 225 \\
\hline Non functioning of ATM machine & 19 & 4 & 12 & 16 & 39 & 21 & 13 & 10 & 28 & 26 & 22 & 15 & 225 \\
\hline Over crowd in their branch & 17 & 3 & 9 & 10 & 5 & 6 & 69 & 29 & 3 & 30 & 16 & 28 & 225 \\
\hline Bank employees are always busy & 8 & 16 & 13 & 18 & 15 & 43 & 23 & 14 & 17 & 1 & 16 & 41 & 225 \\
\hline Lack of bank knowledge & 4 & 25 & 25 & 12 & 19 & 34 & 25 & 15 & 18 & 32 & 5 & 11 & 225 \\
\hline Others(specify) & 9 & 15 & 43 & 61 & 27 & 27 & 2 & 5 & 6 & 23 & 2 & 5 & 225 \\
\hline Total & 225 & 225 & 225 & 225 & 225 & 225 & 225 & 225 & 225 & 225 & 225 & 225 \\
\hline
\end{tabular}

Source: Primary data

Weighted ranking technique has been used to analyse the problems faced by the respondents in internet banking and results are given in Table 6.

Table 6 Problems faced by the respondents - Weighted ranking technique

\begin{tabular}{|c|c|c|c|c|c|c|c|c|c|c|c|c|c|c|c|}
\hline \multirow[t]{2}{*}{ PARTICULARS } & \multicolumn{12}{|c|}{ Ranks } & \multirow[b]{2}{*}{ Total } & \multirow{2}{*}{\begin{tabular}{|l|} 
Mean \\
\end{tabular}} & \multirow{2}{*}{ Rank } \\
\hline & I & II & III & IV & V & VI & VII & VIII & IX & $\mathrm{X}$ & XI & XII & & & \\
\hline Delay in correcting the mistake & 552 & 594 & 220 & 198 & 48 & 28 & 30 & 60 & 40 & 105 & 14 & 2 & 1891 & 10.77 & I \\
\hline Refusal to grant loans to eligible borrowers & 132 & 176 & 140 & 36 & 104 & 105 & 18 & 220 & 164 & 30 & 104 & 2 & 1231 & 7.01 & $\mathrm{X}$ \\
\hline $\begin{array}{l}\text { Unhelpful attitude and discourteous behaviour of } \\
\text { staff members }\end{array}$ & 228 & 165 & 180 & 171 & 72 & 147 & 138 & 160 & 64 & 24 & 24 & 33 & 1406 & 8.01 & VI \\
\hline Delay in giving quick response & 348 & 253 & 140 & 153 & 232 & 42 & 132 & 105 & 108 & 15 & 18 & 23 & 1569 & 8.94 & II \\
\hline Displayed invalid while typing actual PIN number & 180 & 297 & 150 & 162 & 80 & 126 & 180 & 115 & 148 & 18 & 42 & 5 & 1503 & 8.56 & III \\
\hline Complication for transaction of e-banking & 516 & 209 & 70 & 117 & 192 & 154 & 36 & 35 & 12 & 51 & 24 & 52 & 1468 & 8.36 & $\mathrm{~V}$ \\
\hline Shortage of amount in ATM & 60 & 88 & 330 & 135 & 232 & 56 & 24 & 65 & 76 & 96 & 102 & 8 & 1272 & 7.25 & IX \\
\hline Non functioning of ATM machine & 228 & 44 & 120 & 144 & 312 & 147 & 78 & 50 & 112 & 78 & 44 & 15 & 1372 & 7.82 & VII \\
\hline Over crowd in their branch & 204 & 33 & 90 & 90 & 40 & 42 & 414 & 145 & 12 & 90 & 32 & 28 & 1220 & 6.95 & $\mathrm{XI}$ \\
\hline Bank employees are always busy & 96 & 176 & 130 & 162 & 120 & 301 & 138 & 70 & 68 & 3 & 32 & 41 & 1337 & 7.62 & VIII \\
\hline Lack of bank knowledge & 48 & 275 & 250 & 108 & 152 & 238 & 150 & 75 & 72 & 96 & 10 & 11 & 1485 & 8.46 & IV \\
\hline Others(specify) & 108 & 165 & 430 & 549 & 216 & 189 & 12 & 25 & 24 & 69 & 4 & 5 & 1796 & 10.23 & \\
\hline Total & & & & & & & & & & & & & 17550 & & \\
\hline
\end{tabular}

Source: Primary data

Most of the respondents gave I rank to the statement 'Delay in correcting the mistake' with the mean score of 10.77 followed by 'Delay in giving quick response' with the mean score of 8.94 .

\section{CONCLUSION}

Customer perception is indeed a measurement that fulfills the general expectations of a customer. The study analyse the difference between the customer's ideal bank in his mind and the present scenario the responsiveness is a factor which is considered for measuring the perception of the respondents towards internet banking followed by courteous service.

\section{REFERENCES}

1. Hasanbanu, S. (2004), "Customer service in rural banks: An Analytical study of Attitude of Different types of customers towards banking services", IBA Bulletin, Vol.XXV1, No. 8(August), pp.21-29.

2. Mathivanan, B, and Kavitha, "A Study on Consumer Perception towards EBanking Services of ICICI Bank",IJIRD, Vol.4 Issue 12, pp.20.

3. Khan M S, Mahapatra S S and Sreekumar (2009), "Service Quality Evaluation in Internet Banking: An Empirical Study in India", Int. J. Indian Culture and Business Management, Vol. 2, No. 1, pp. 30-46. 